\title{
Missionaries and Orientalists Studies of Chinese Islam- Before the 20th Century
}

\author{
Alimu Tuoheti ${ }^{1}$ \\ ${ }^{1}$ Tohoku University, Japan \\ Correspondence: Prof. Alimu Tuoheti, Tohoku University, Japan. \\ Received: March 29, 2021 \\ Accepted: July 14, $2021 \quad$ Available online: July 16, 2021 \\ doi:10.11114/ijsss.v9i5.5296 \\ URL: https://doi.org/10.11114/ijsss.v9i5.5296
}

\begin{abstract}
In the $19^{\text {th }}$ century, the development of natural science and the emergence of enlightenment gradually gave birth to social science in modern Europe. As Europe opened the door to China in the middle of the $19^{\text {th }}$ century, Western academia began to pay attention to China, and Western theories and methods progressively entered China and were accepted by Chinese scholars. Most saliently, some Christian missionaries and Orientalists have completed more serious studies of Islam in China, and published several corresponding works and research results on this basis. During this period, those who studied Islam and Muslims in China could be divided into two categories. the Religious people, including Christian missionaries. and Scholars, including Orientalists. Subsequently, when Western missionaries entered China, they found the presence of a large Muslim group, so they began to study them and organize missionary work. Although this missionary activity proved unsuccessful in terms of the number of converts to Christianity, it maintains a certain positive significance regarding religious and cultural exchange, and cross-civilizational interaction. Documents recording the encounters between Christianity and Islam in China since modern times are scattered in journals such as Chinese Repository, The Chinese Recorder, Friends of Moslems, The Moslem World and China's Millions.
\end{abstract}

Keywords: European and American, mainland China, Islam, Muslim, academic studies

\section{Introduction}

In the Middle Ages, Christianity provided the main channel of communication between the West and China, Christianity having been introduced to mainland China from West Asia via Central Asia. In the Tang period, Christianity was called "Jing jiao". In the 14th century, the Vatican sent Catholic missionaries to mainland China to preach. At that time, during the Yuan period, Christianity was called "Ye li ke wen jiao".

After the collapse of the Yuan dynasty, the "ye li ke wen" religion - well treated by the ruling class - vanished, its disappearance coinciding with the Western Schism in the Vatican. Central Asia was plagued by wars and diseases, and the east west land transportation line was blocked. However, after the Ming dynasty replaced the Yuan dynasty, a closed-door policy was implemented, slowing Christian missionary activity in the mainland. However, with the opening of the new route, the ships of the Portuguese, Spanish, and other colonial powers not only brought trade to the coastal areas of the Ming dynasty but also founded strongholds for Catholic missionaries. In the past two hundred years, the Holy See had undergone religious reform and the Catholic Church had produced a confrontation between Jesuits and Protestants. The Pope wanted to take advantage of the Jesuits' missionary activities to occupy the parish in the East for himself. In the middle of the 16th century, the Jesuit Shabu tried and failed to preach in China's interior. Subsequently, the Jesuit missionary Matteo Ricci ${ }^{1}$ knocked at the door of the Ming dynasty, marking the beginning of Catholicism's first small climax of missionary work in China.

These Catholic missionaries, represented by Matteo Ricci, called themselves "Western monks" when they first entered China, and dressed in Buddhist monk clothing. Later, under the influence of local literati, they exchanged their monks' clothing for Confucian clothing. Their missionary aim was to adapt to Chinese culture and to spread Western learning. Therefore, to mitigate obstacles to the spread of Christianity in China, they studied ancient Chinese classics, used

\footnotetext{
${ }^{1}$ Italian Pronunciation; Latin: Mattheus Riccius Maceratensis (6 October 1552-11 May 1610). Ricci was an Italian Jesuit priest and one of the founding figures of the Jesuit China missions. He created the Kunyu Wanguo Quantu, a 1602 map of the world written in Chinese characters. He is considered a Servant of God by the Catholic Church.
} 
Confucianism to demonstrate Christian doctrines, recognized Chinese etiquette and customs, and strove for the support of the ruling class. At the time of Matteo Ricci's death, there were more than 2000 Catholics China. Churches had spread to Zhaoqing, Shaozhou, Nanchang, Nanjing, Beijing, Shanghai, Hangzhou, and other places, attracting more believers.

But the longhuamin who succeeded Matteo Ricci as the president of the Jesuits in China, insisted on a different way of preaching from his predecessor. He insisted that Chinese Catholics abandon their traditional customs, which led to many counter-preaching movements. Nevertheless, Catholicism succeeded in establishing the independent Far East Missionary Province in China, and by the end of the Ming period, there were more than 100,000 Catholics. Despite a dispute over the old and new calendars, the missionaries won the trust of the ruling class, and were able to revise the calendars after the reign of the Qing dynasty. By 1701, China's Catholicism had three dioceses - Macao, Nanjing, and Beijing - with 130 missionaries and about 300,000 believers. However, the contradiction between Catholicism and Chinese traditional culture again reached a critical point, coming to a head in the "etiquette dispute" of 18th century over whether the Catholics should adapt to Chinese culture. The focus of the debate was on the name of "God", and the rituals and customs of the worship of ancestors and Confucius. The second debate, in particular, provoked conflict between the Jesuits and the Holy See: the Jesuits tried to protect the rationality of their preaching ideas and methods, while the Pope repeatedly stressed his own authority and that of the Holy See. The Qing dynasty also needed to affirm the legitimacy of traditional culture, which finally led to Kangxi's ban in 1717 and the suspension of all Catholic missionary activity in China.

The debate lasted for nearly a hundred years. From the Yongzheng (雍正) dynasty until the Opium War, the European Catholic missionary cause in China was greatly hit. As a legacy of the border dispute between the Great Qing dynasty and Russia, the Russian Orthodox Church formally sent the Orthodox missionary group to China, with the consent of Emperor Kangxi. In 1716, the Chinese Orthodox Church was established in Nicholas Church in Beijing. However, it was different from the organization of the Catholic Church's missionary activity, such as that of the Jesuits. China's Orthodox Church was also the diplomatic agency of the tsarist government in Beijing, and later provided the venue for tsarist envoys and businessmen who came to China.

After the Yongzheng dynasty, the Jesuits were disbanded by the Holy See; the Catholic missionary activities weakened, and secret missionary activity was maintained in only a few places. At the beginning of the 19th century, with the rapid development of colonization and expansion of new capitalist countries, Protestant preaching first entered China. Morrison was the country's first Protestant missionary, but because the Qing dynasty maintained its policy of banning religion, his activities were as low-key as possible, and writing was a more appropriate way of conducting missionary work. Morrison learnt Chinese and translated the New and Old Testaments, publishing Chinese versions - the first time the missionaries had produced a complete Chinese version of the Bible. Early Protestants such as Morrison were unable to preach in mainland China due to Qing's restrictions. Accordingly, they were mainly engaged in the translation of Christian books or the promotion of Christian thinking and doctrine by writing books in Chinese. Other effective methods included practicing medicine or running a school. Morrison's school, the first Western-style college in China, was founded in Macao in 1839.

In 1834, American Pastor Bojia, an American, arrived in Guangzhou to engage in medical missionary work - the first missionary doctor. He established organizations such as the ophthalmic medical bureau and the Chinese Medical Missionary Association, which won the trust of the local people. After the Opium War, the policy of banning religion over 100 years - began to loosen. The Huangpu Treaty between China and France, in addition to paving the way for building churches at trading ports, allowed the restoration of previously destroyed chapels and cemeteries, etc. In this way, although the missionaries had not yet gained the right to preach in mainland China, Catholicism and Protestantism jointly ushered in a new era of Christian missionary activity in the country. By the end of the 19th century, with China opening its doors to the West, both archbishops and Protestants had strengthened missionary activities in the mainland. In this context, Catholicism mainly absorbed the middle and lower-classes as believers; Protestantism, meanwhile, paid more attention to cultural, educational, medical, and other aspects of work to expand the influence of Christianity in society.

During this period, the feudal system of most European countries was undergoing a critical period - from prosperity to decline - but the momentum of the capitalist economy was very promising, and the social economy was flourishing. Culturally, in post-16th century Europe, there had been a strong trend of reform within the church. Europeans had viewed the ancient East as mysterious, and the pagan countries in particular. However, when The Travels of Marco Polo was published and translated into many European languages, tens of thousands of Europeans became interested in Ancient China. China's political system and economic prosperity became a major attraction for Europeans, and more directly China became a suitable venue for missionaries' dreams and endeavors. In this context, missionaries came to China to collect myriad kinds of information pertaining to ancient oriental civilization, at the same time that the 
European continent was providing excellent learning resources for political systems requiring change. Chinese ideas played an important role in European renewal and the construction of European culture.

Before the 19th century, records of Hui Islam in China existed in Europe - one of the most famous was in Marco Polo's travelogue - but at that time, there was no academic research in the contemporary sense. The development of natural science and the emergence of the Enlightenment in the 19th century gradually gave birth to the social sciences of modern Europe. By the middle of the 19th century, the eyes of Western scholars also turned to China. Subsequently, Western theories and methods were gradually introduced into China and accepted by Chinese scholars.

It is generally acknowledged that the international study of Chinese Islam began in the second half of the 19th century. By 1840, China, which had long been closed, was opened by Western warships. Henceforth, a large number of Western missionaries, scholars, and explorers followed the army and businessmen into the hinterland of China, witnessed the life of Chinese Muslims, and made contact with them. Gradually attention began to be paid to Chinese Islam.

Most saliently, some Christian missionaries and Orientalists began to conduct a more serious study of Islam in China, publishing several corresponding works and papers.

On one hand, the missionaries' attention to Islam in China derived from the requirements of missionary work; conversely, Islam was a religion that missionaries were familiar with and regarded as an important competitor. Russian Orthodox missionaries were the first to collect information about Chinese Islam. Two groups first began to collect information about the Islam of Hui nationality in China: Christian missionaries and Orientalists.

Upon entering China, Western missionaries discovered the presence of a large Muslim group, which they began to study and targeted with their missionary work. Although this missionary activity was not successful in terms of the number of the converts to Christianity, it produced a certain positive significance regarding objective religious and cultural exchange and civilizational interaction.

Documents recording the encounter between Christianity and Islam in China in modern times are scattered in the following journals: Chinese Repository; The Chinese Recorder; Friend of Moslems; The Moslem World; China's Millions.

These journals reflect the Western perspective, as well as related works of missionaries, records of missionaries' conferences, Hui newspapers, and local Chinese historical records, and more.

\section{Russian Orthodox Missionaries}

The development of Chinese Islamic studies is closely related to the activity of missionaries from different countries. In the 19th century, the Russian Orthodox Church - one of the three major Christian factions - became the first to gain the privilege of preaching in China, although the scale and impact of its development were not as prominent as that of the Protestant churches of the same denomination. However, the Russian mission still made considerable achievements in the study of Chinese Islam.

The earliest contact between the Russian Orthodox Church and modern China can be traced back to the middle and late 17th century. However, due to the Qing government's increasingly strict policy of banning religion and closing customs, for more than a hundred years after first contact, Russia's overall concern and understanding of China was quite limited. By the 19th century, the situation had changed dramatically. Russia had a positive interest in the Far East. In 1801, a new constitution was established for trade between Russian merchants and the Chinese in Chiaktu. In 1805, a fleet was dispatched to sail around the world and it was arranged for a new mission headed by Count Glovkin to be sent to China. $^{2}$

Around 1807, the tsarist government also subordinated its mission in Beijing. It was adjusted to be run by the Russian Ministry of Foreign Affairs from the jurisdiction of the Siberian governors, and additional guardians were sent to the Beijing mission. In 1818, the tsarist government issued an order to its missions in China, stipulating that "the main task in the future is not religious activities, but to conduct a comprehensive study of China's economy and culture, and to report major events in China's politics to the Russian Foreign Ministry promptly". ${ }^{3}$ In the 19th century, the tsarist government's need and desire to understand China seemed to be more pressing.

As a result of these economic, military, political, and cultural factors, Russia's interest in and attention to China reached an unprecedented level in the 19th century. There had already been one hundred years of continuous missionary activity in China, involving Chinese business, politics, geography, customs and culture, religion, and history.

\footnotetext{
2 P. K. I Quishtad, 1979, 1857-1960 Russian expansion in the far East, The Commercial Press.

${ }^{3}$ Wu Keming, 1985, A Brief History of Russian Orthodox Invasion of China, Gansu People's Publishing House.
} 
In this context of the Russian Orthodox Church entering China, the missionaries launched multiple successful studies on China. A group of outstanding sinologists - and for Russia, the development of modern sinology in China - laid a solid foundation with a bright future. Prominent scholars of Islam and western regions in China included Hyacinth Yakovlevich Bichurin, Vasili P Vasilev, and Archimandrite Palladusu.

\subsection{Hyacinth Yakovlevich Bichurin}

As the founder of Russian sinology and Orientalism, sinologist Hyacinth Yakovlevich Bichurin (Никита Яковлевич Бичурин, 1777-1853) spent a lengthy period in Beijing as the ninth head of the Russian Orthodox Mission in East China and published nearly one hundred works on China. He was the first person in the hundred-year history of the Russian Orthodox Mission in East China to bring Chinese scholars and their academic achievements to the attention of all sectors of Russian society, and in Russian. His Russian translations of works by European missionaries significantly increased Russian familiarity with China, and he is considered the pioneer of many research fields of Russian sinology.

Bichurin's in-depth research on Chinese society and culture is meticulous, making effective use of important Chinese classics and laying down a reliable foundation for later Russian sinologists in terms of historical data. This focus on Chinese classics also indicated that the Russian sinology tradition he established differed from contemporary missionary writing in Europe. At the time, European sinology was dominated by the writing of missionaries and travelers, which largely drew on what the authors saw and heard, and even on hearsay. The studies of Bichurin and later Russian sinologists were based on Chinese classics, which were more scientific and rigorous, and were therefore more in line with the norms of modern disciplinary research. His academic vision and position earnt him not only the admiration of Russian scholars but also the respect of Europe.

The research based on Chinese classics initiated by Bichurin influenced the sinologists who broadly made up the members of the Orthodox Mission in East China at that time. The works in four volumes published in the second half of the 19th century, Works of members of the Russian Spiritual Mission in Beijing, ${ }^{4}$ contain studies of Chinese history, geography, and the astronomical calendar, based on different Chinese classics.

In the study of the history and geography of Islam in western regions, the representative translations are as follows:

(1) In 1833, Bichurin published The History of Tibet and Qinghai (2282-1227BC) 5 in St. Petersburg. The contents of the book are mainly translated from Twenty-Three Histories and History as a Mirror. The book is divided into two parts: the first part involves the origin of tanggute, the political relationship and war with China, the conquest of China, China and tanggute, and the origin of Tibet; the second part details tanggute, Qidan, and Chinese. At the end of the book are maps of various historical periods in the northeast and west of Tibet, as well as a list of ancient and modern place names. Also, several articles are attached which serve as introductions to the chronology, system of measurement, and coins of China. Compared with previously published works on Tibet, this book attracted more attention from orientalists. Although Bichurin's translation is not strictly a historical work on Tibet and Qinghai, it is still of great reference value to historians.

(2) In 1829, Bichurin published another work on the study of the history and geography of ethnic minorities in China's border areas: The Ancient and Present Records of Junggar and East Turkestan, based on The History of the Former Han Dynasty, Memoirs on the Western Regions, Records of Western Regions, and A Survey of Geography and Figures of the Western Region. At the end of the book, an ancient place names index and a table for comparison with the place names of the 19th century are attached. Bichurin's groundbreaking book was the first in Russia on the history of western China.

(3) In 1834, Bichurin published The History of the Irutos and Kalmecks since the 15 th Century ${ }^{6}$ and in 1851 , The Compilation of the Historical Materials of the Ancient Central Asian Nations. ${ }^{7} 7$ These books were based on Xinjiang Knowledge, and Records of Western Regions. He used a large number of Chinese materials, making the book an essential reference for scholars of Mongolian history. Additionally, Bichurin founded the first Chinese language school

\footnotetext{
${ }^{4}$ As head of the mission, Palladusu initiated, organized, edited, and published a collection entitled Works of members of the Russian Spiritual Mission in Beijing, which enjoyed a wide influence in international sinology circles. The book consists of four volumes and was published by the printing house of St. Petersburg Military Academy.

${ }^{5}$ Hyacinth Yakovlevich Bichurin (Никита Яковлевич Бичурин), 1833, The History of Tibet and Qinghai (22821227BC), St. Petersburg.

${ }^{6}$ Hyacinth Yakovlevich Bichurin (Никита Яковлевич Бичурин), 1834, The History of the Irutos and Kalmecks since the 15th century, St. Petersburg

${ }^{7}$ Hyacinth Yakovlevich Bichurin (Никита Яковлевич Бичурин), The Compilation of the Historical Materials of the Ancient Central Asian Nations, St. Petersburg, 1851.
} 
in Chiaktu in 1831. This school trained several talented Chinese translators for Russian business, politics, culture, and other fields.

Bichurin widely used Chinese documents in his study of Muslim ethnic history and geography in the border areas, and collected and translated a large amount of invaluable material. Since the disciplines of archaeology and anthropology were in their infancy at the time and could not, therefore, provide auxiliary materials for his research, Chinese classics became the only rich and reliable source of information. Using Chinese documents, he made a great contribution to the development of Russian sinology and Islamic studies, and was highly praised by all sectors of Russian society.

\subsection{Archimandrite Palladusu}

The 12th member of the Russian Orthodox Mission to China, the 13th and 15th foreman Palladusu (Архимандрит Палладий) (1817-1878), was also a sinologist who was highly valued by the Russian government in the middle and late 19th century. A graduate of St. Petersburg Seminary, he visited China several times and was active in the country for more than 30 years. His research contribution to the fields of Chinese linguistics, history, and geography, was extensive. During his first sojourn in China, Palladusu studied Buddhism and translated Buddhist scriptures from Chinese, Mongolian, and Tibetan. In his later years, Palladusu became interested in Chinese Islamic literature and published two articles. The first, "Muslims in China", was published in The Fourth Volume of the Works of the Russian Missionaries in Beijing in 1866. The second, "Chinese Islamic literature and Interpretation of the Chinese Islamic Anthology Compiled by Liu Zeliang, a Chinese Islamist", was published in Volume 17 of The Oriental Works of the Russian Geographical Society in 1877.

Palladusu's most famous work on Islamic studies is Selected works of Islamic Chinese, ${ }^{8}$ running to a total of 334 pages. It was published in St. Petersburg in 1887 with the help of Belschneider (1833-1901), a former Russian Embassy doctor. The manuscript of the book was found by Father Adoratsky in the archives of the Russian Orthodox mission in Beijing after the Palladusu's death. Palladusu also studied the history of the introduction of Christianity into China. In 1872,

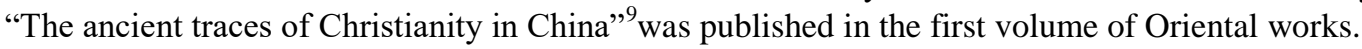

Palladium also published work on the history and religion of the border areas. His study of Mongolia, focusing on its early history in the Genghis Khan period, is still valued by historians. In 1866, Palladusu published his translated Secret History of Yuan Dynasty ${ }^{10} 10$ in the fourth volume of the works of the members of the Russian mission in Beijing. The original text came from the Yongle Dadian, with 660 notes and a foreword introducing its history. His translation and study of the secret history of the Yuan dynasty made him a great master in the study of Russian Mongolian history. He also translated and annotated The Legend of Genghis Khan in China, The Pilgrimage to the West of Changchun, and The Pilgrimage to Mongolia of Zhang Dehui in the First Half of the 13th Century. Most of these works contain information that relates to Islam and Muslims in the western regions.

During his mission in Beijing, he collected information about Islam in China, which was translated and published in Australia in 1977. Palladusu also set up a continuous journal devoted to the study of China, some volumes of which were translated into German.

\subsection{Vasili P. Vasilev}

Vasili P Vasilev (Василий Павлович Васильев,1818-1900), a member of the 12th Russian Orthodox Mission to China, was an important figure in the field of Russian sinology in the middle and late 19th century. In 1834, he entered the Oriental Department of Kazan University to study Manchu, Chinese, and Mongolian. In 1837, he obtained a master's degree for his thesis, On Principles of Buddhist Philosophy. In 1840, he traveled to Beijing. Subsequently, Vasiliev began to study the languages, history, geography, culture, religion, statistics, commerce, customs, and other elements of various ethnic groups in China, including Han, Manchu, Mongolian, and Tibetan, and produced a large research corpus.

In 2014, China's Publishing House published Vasili P Vasilev's History of Chinese Literature, ${ }^{11}$ which comprises 15 consecutive sections. This work introduces Confucianism, Buddhism, and Taoism, as well as ancient Chinese texts on history, geography, religion, and literature. Vasili's introduction, data collection, and guiding research of Chinese literature hadlaid a solid foundation for the specialization of Russian sinology in the 20th century.

\footnotetext{
${ }^{8}$ Archimandrite Palladusu (Архимандрит Палладий), 1887, Selected works of Islamic Chinese, St. Petersburg.

${ }^{9}$ Archimandrite Palladusu (Архимандрит Палладий), 1872, “The Ancient Traces of Christianity in China," Oriental Anthology, Vol. 1.

${ }^{10}$ Archimandrite Palladusu (Архимандрит Палладий), 1866, "Secret History of Yuan Dynasty," Works of Members of the Russian Missionary Group in Beijing, Vol. 4.

${ }^{11}$ Vasili P Vasilev, 2014, "History of Chinese Literature”, China’s Publishing House, p. 168.
} 
The Appendix to this book is as follows: 1) Contents of Vasilev's main works; 2) Vasilev's relevant archives and their locations; and 3) Vasilev's manuscripts and their locations, and a detailed summary of his publications.

Vasilev's research is introduced and described in the book Vasili P Vasilev and China. ${ }^{12} 12$ This book gives a detailed overview of Vasilev's The History and Monuments of Eastern Central Asia in the 10th-13th Century (1859)..$^{13}$

For the study of the history and geography of Islam in the western regions, we find "O dvnshenii magometanstva $\mathrm{V}$ Kitae" translated as "Islamic Movement in China" (1867).${ }^{14} 14$ The Edinburgh Weekly published the English translation of Chinese Islamic articles in Russian military journals (1868).

Rudolf Lowenthal translated Vasilev's work from Russian into English, where it appeared as Islam in China in $1960 .{ }^{15}$

After his return from China in 1850, Vasilev was increasingly engaged in the development of sinology in the Oriental departments of Kazan University and St. Petersburg University and won the title of academician of the Russian Academy of Sciences in 1866.

In the history of Russian sinology, Hyacinth Yakovlevich Bichurin, and his descendants Vasili P Vasilev and Archimandrite Palladusu, were honored as the "three giants" of Russian sinology in the 19th century and contributed greatly to Russian sinology, surpassing European efforts in the field.

Compared with Western Europe, some aspects of the study of Chinese Islam by Russian Orthodox missionaries in the 19th century were weak; however, thanks to the proximity of Russia and China, the support of the Russian government, the preferential policies of the Qing dynasty and the efforts of the missionaries themselves, the Russian Orthodox missionaries not only produced the excellent research described above but also gradually shaped the research characteristics of Russian Islamic studies in general and laid a solid foundation for the subsequent development of the discipline.

\section{The China Inland Mission (CIM) and China's Millions}

In the first half of the 20th century, the missionary work of the Western Christian Church in China reached its peak. The China Inland Mission, or CIM, (a transnational missionary organization in China) was reflective of this. Founded in 1865 by English missionaries, including Hudson Taylor (1832-1905), its missionaries who were sent to China came from different sects and nations, mainly Great Britain, the United States, Canada, and New Zealand. Some were also from Germany, Austria, and Northern Europe (countries such as Sweden, Norway, Finland, and Denmark). The CIM asked missionaries to devote themselves regardless of payment and allow themselves to be Sinicized. As a result, they became the vanguard of missionaries in mainland China. They set up missionary stations and then expanded rapidly to the most remote areas. By the end of the 19th century, the CIM had about 650 missionaries, 270 missions, and 5000 believers, becoming the largest Protestant group in China. In this context, missionaries began to investigate and study Islam in China from the perspective of Muslim missionary work. During this period, the study of British and American missionaries in the field of Hui Islam in China peaked.

\subsection{About the China Inland Mission (CIM)}

The CIM was an international Christian missionary organization founded in 1865 by James Hudson Taylor of England. In 1964, it was renamed the overseas mission fellowship or OMF International.

In September 1853, Hudson Taylor was sent from England to China by the Chinese Missionary Association of Britain, first preaching in Shanghai, Shantou, and other places. In 1857, he settled in Ningbo and established the Ningbo Mission, until he left following a disagreement with the Chinese Missionary Association. In 1860, illness forced Taylor to return to England, where he spoke widely, calling on people to preach in China. In 1865, Reverend Taylor changed the name of the Ningbo Mission to the China Inland Mission, and established its evangelist policy; specifically, to recruit a group of missionaries who could move to mainland China for long-term work, introducing and disseminating Christianity. In 1867, the Taylor family and 16 missionaries returned to China. They mainly frequented the hinterland to preach, reaching as far as Tibet, Qinghai, Xinjiang, and other distant destinations. In 1890, a philanthropist donated money for the construction of the headquarters of the Mainland Society in Shanghai, to serve as offices and housing for more than 300 missionaries. The public relations and education center of the Mainland China Association was originally located in Hangzhou. In 1890, it

\footnotetext{
122 Zhao Chunmei, 2007, "Vasilev and China”, Xuefan publishing house,p. 219.

${ }^{13}$ Vasili P. Vasilev, 2007, "The History and monuments of Eastern Central Asia in the 10th - 13th Century" (1859) in Zhao Chunmei: "Vasilev and China", Xuefan publishing house.

${ }^{14}$ Vasili P. Vasilev, 2007, "Islamic Movement in China “ (1867) .

${ }^{15}$ Vasili P. Vasilev, 1960, "Islam in China”, Central Asian Collectanea.
} 
moved to Shanghai. Gradually, the public relations and education work stretched further into the interior of China and reached Dihua (now Urumqi) in Xinjiang. It was not until the 1950s that it withdrew from China against the political backdrop of the Cold War.

In a broad sense, research on the CIM began in the late Qing dynasty as a result of the evangelist work of the Inland Mission itself.

J. Howard. Taylor, the founder, wrote and published the general historical works of the China Inland
Mission in 1900.
J. Howard. Taylor, Three Decades of The China Inland Mission, Toronto: The China Inland Mission,
1900.

Other missionaries, following suit, wrote and published:

F. Howard. Taylor, Those Forty Years: A Short Story of The China Inland Mission, Philadelphia: Paper
Pub, 1903.
Marshall Broomhall, The Jubilee Story of The China Inland Mission, London: China Inland Mission,
1915.
$\begin{aligned} & \text { Leslie T. Lyall, A Passion for The Impossible: The China Inland Mission, 1865-1965, Chicago: } \\ & \text { Moody Press, 1965. }\end{aligned}$

The Inland Mission also attached importance to the writing and publishing of missionary biographies:

\begin{tabular}{l}
$\begin{array}{l}\text { Mrs. Mark Botham, Two Pioneers: Life Sketches of Thomas and Mark Botham, London: Marshall, } \\
\text { Morgan and Scott, } 1929 .\end{array}$ \\
\hline Frank Houghton, George King: Medical Evangelist, London: China Island Mission, 1930. \\
\hline $\begin{array}{l}\text { Mildred Cable and Francesca French, The Making of a Pioneer: Percy Ma Ther of Central Asia, New } \\
\text { York: Frederick A, Stokes, } 1935 .\end{array}$ \\
$\begin{array}{l}\text { Mildred Cable and Francesca French, George Hunter: Apostle of Turkestan, London: China Inland } \\
\text { Mission, 1948. }\end{array}$
\end{tabular}

Most of the CIM's historical works and biographies were written before they left mainland China. The writing was for public relations purposes and education at the time but nevertheless was founded on rigorous academic research, thus providing important material for this research.

Academic research on Islam increased after the reform. To the present day, there have been many dissertations in Chinese academic circles, e.g., Du Yanbo's The Research on the Activity of the China Inland Mission in the Modern Northwest Muslim Society. ${ }^{16}$

Some monographs have been published in this field, of which the most important include: Alvyn Austin, China's Millions: The China Inland Mission and Late Qing Society, $1832-1905,{ }^{17}$ and Alvyn Austin's Only Connect: The China Inland Mission and Transatlantic Evangelicalism. ${ }^{18}$

\subsection{China's Millions}

China's Millions was the English-language journal of the China Inland Mission, the largest Western missionary organization in China. The journal was one of the most valuable databases for the understanding and study of the missionary cause of the Mainland Society, headed by Thomas Hudson Taylor and the Modern Chinese Society.

The full set of the original publication is now in the archives of the Asian African Institute, University of London, UK. In the 89 years from 1875 to 1964 , it published more than 90 volumes. An important medium, its growth has had a profound

\footnotetext{
${ }^{16} \mathrm{Du}$ Yanbo, 2009, The Research on the Activity of the China Inland Mission in the Modern Northwest Muslim Society, Master Thesis of Xinjiang Normal University.

${ }^{17}$ Alvyn Austin, 2006, China's Millions: The China Inland Mission and Late Qing Society, 1832-1905, Mich.: Wm. B. Eerdmans Publishing Company.

${ }^{18}$ Alvyn Austin, 2003, “Only Connect: The China Inland Mission and Transatlantic Evangelicalism”, in North American Foreign Missions,1810-1914: Theology, Theory, and Policy, ed. Wilbert R. Shenk (London: Gurzon and Grand Rapids: Eerdmans).
} 
impact on Chinese and Western society.

The journal included a number papers or works on Chinese Muslims and Islam:

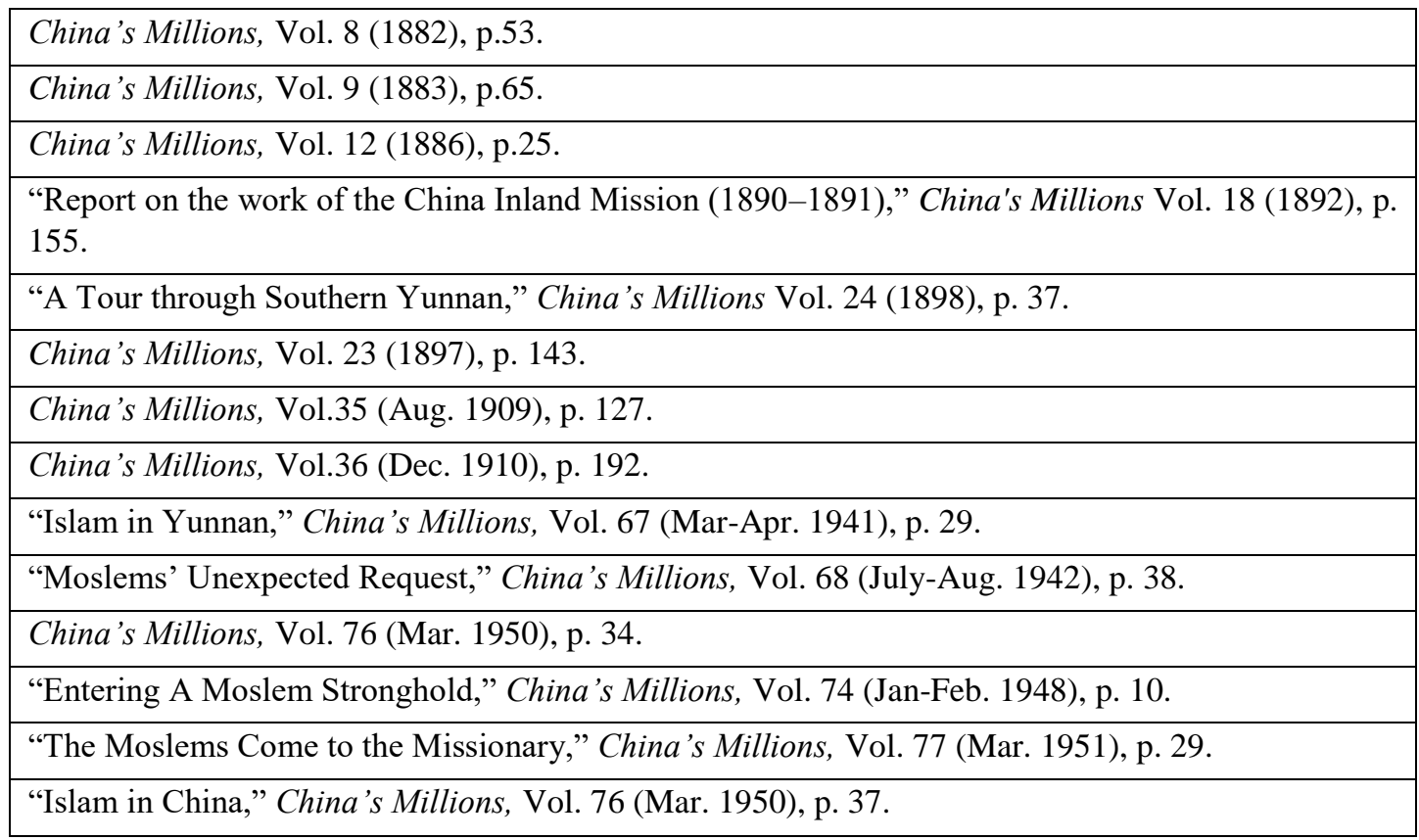

\subsection{The Relationship between Christianity and Islam in Modern China}

The Christian missionary activities aimed at Chinese Muslims are an important aspect of the study of the relationship between Christianity and Islam in Modern China.

In this regard, as early as 1985, the Hebrew University developed a subproject to carry out related research. In 1995, its project leader, Raphael Israeli, published the first comprehensive research paper about the interaction between Christianity and Islam in China. This paper discusses the Christian missionaries from 1850-1950. ${ }^{19} 20$ Chinese Muslim responses to their work suggest that "the interaction between Christianity and Muslims was not fixed, nor one-way from Christianity to Islam. Rather, they are considered dialectically related, challenging and influencing each other, their ups and downs depending on their destiny in China."

Other publications on the relationship between Christianity and Islam in China include:

Francoise Aubin, 'L' Apostolat Protestant en Milieu Musulman Chinois," in Chine et Europe: Evolution et Particularites des Rapportes Est-Ouest Du XVle ou XXe Siecle, 1991.

Ralph R. Covell. The Liberating Gospel in China: The China Faith among China's Minority Peoples, Grand Rapid: Baker Book House Company, 1995.

Fang Jianchan. "Missionary activities of modern Western Christian missionaries in Northwest China and a summary of relevant documents", Northwest Ethnic Studies, 1994 (1).

In this 1994 paper, Fang Jianchang briefly introduces the missionary activities and works of several important missionaries.

\begin{tabular}{l} 
Liu Jiafeng, "Research Review and Prospect of the Interaction between Christianity and Islam in \\
Modern China," World Religious Culture, 2011 (3), p. 78. \\
\hline Matsumoto Masumi, "Protestant Christian Missions to Muslims in China and Islamic Reformist \\
Movement," Annals of Japan Association for Middle East Studies, Vol. 21, No. 1, 2005.
\end{tabular}

This paper discusses the missionary activities and Chinese Muslim responses to Christianity. It offers many salient points, for example, Christian missionaries upholding the Western-centered cultural mentality and the sense of Christian superiority, and that the Islamic Reform Movement in Modern China is related to Christian missionary activities.

\footnotetext{
${ }^{19}$ Raphael Israeli, "The Cross Battles the Crescent, One Century of Missionary Work among Chinese Muslims, 19851950,” Modern Asian Studies, Vol. 29, No. 1, 1995.
} 


\begin{tabular}{l} 
Mildred Cable and Francesca French. George Hunter Apostle of Turkestan. London: China Inland \\
Mission, 1948. \\
Bradshaw, Malcolm R. Torch for Islam A Biography of George K. Harris, Missionary to Muslims. \\
London: China Inland Mission, 1965. \\
Andrew George. Findley. The Crescent in North-West China. London: The China Inland Mission, \\
1921. \\
\hline Strong, Anna Louise. China's millions. New York: Coward-McCann. Inc, 1928. 413pp \\
Du Yanbo, 2009, The Research on the Activity of the China Inland Mission in the Modern Northwest \\
Muslim Society, Master Thesis of Xinjiang Normal University.
\end{tabular}

Du Yanbo's thesis studies and analyses the literature pertaining to the Christianity missionary activities, especially those of the CIM in the northwestern region, which includes our country and other countries. Part 2 introduces the CIM and its background. Part 3, the most important section, describes the position of the CIM in northwest Muslim society, and it points out its typical role and important functions. It also describes specific missionary activity. Part 4 provides a comprehensive and systematic analysis of the effects of some of the CIM's exemplary activities. Firstly, it examines the successful contact between missionaries and Muslims, and the more favorable conditions that they constructed. The author concludes that it is not straightforward to assess whether the CIM's contacts and dialog were a "success" or not; instead, we should view the question from multiple angles, which is the primary premise of understanding historical missionary outcomes. Meanwhile, it explores the inner root of the failure of missionary work, which includes society, politics, history, religion, and so on. It then points out that the failure was inevitable. Part 5 concludes the paper by asserting that the historical influence of missionaries is both positive and negative; as well as reflecting on religious dialog and work." 20

Regarding the Liu Xuha thesis: "The dissertation focuses on the missionary work by the China Inland Mission (CIM) to the Moslems in the northwest of China. The missionary work started in 1876 when the missionaries of CIM entered northwest and came to an end in 1951. Previous studies on the CIM involved the missionary work by CIM to Moslems, but the analysis was neither systematic nor complete or deep. The key historical material is also seriously lacking. Meanwhile, the micro-view and macro-view studies on the relationship between Protestant and Islam in modern China are strong but the medium-view study is very weak. Based on these, the study of this dissertation is very necessary and it can supplement the inadequacy of the study on the CIM and in can also strengthen the medium-view study on the relationship between Protestant and Islam in modern China." ${ }^{21}$

Du Yanbo Master's thesis and Liu Xuha's doctoral dissertation are of the highest reference value.

\section{The Chinese Recorder and Missionary Journal ${ }^{22}$}

Many research papers on Chinese Islam and Muslims have been published in The Chinese Recorder and Missionary Journal. The relationship between this journal and the study of Chinese Islam therefore requires exploring.

Protestant missionaries in China founded this English language journal in 1867 and it ran for 75 years. It was the predecessor of The Missionary Recorder, published one year earlier. It was reprinted in Shanghai in 1874, two years after its suspension. It was officially named The Chinese Recorder and Missionary Journal in 1915 and published in both Chinese and English. It was suspended after the outbreak of the Pacific War in 1941.

The Chinese Recorder and Missionary Journal is of great significance to the study of the history of missionaries during the period 1845-1941 and, at the same time, was also the most famous monthly magazine in Western newspapers. The importance of the journal is mainly reflected in the fact that missionaries in China had to not only preach in China, but also provide feedback about the progress to the mother church and communicate with Chinese missionaries. These exchanges involved all aspects of their life and work, including face-to-face introductions. The overview sheds light not only on the missionaries' situation but also on China's social circumstances. The journal attracted the attention of a

\footnotetext{
${ }^{20}$ Du Yanbo: The Research on the Activity of the China Inland Mission in the Modern Northwest Muslim Society, Master Thesis of Xinjiang Normal University, 2009.

${ }^{21}$ Liu Xuha: Study on The Missionary Work by The China Inland Mission to Moslems in Northwest of China (1876-1951), Doctoral dissertation, Central China Normal University, 2012.

${ }^{22}$ The object of this chapter is academic research history before 1900, but here, given the needs of this specific topic, it extends to 1941 .
} 
group of influential missionaries, leading to increased circulation and popularity among missionaries in China.

Overall, the purpose of The Chinese Recorder and Missionary Journal was to serve missionaries in China and help them exchange information with each other. Its 75-year publishing history represents the thoughts and insights of mainstream churches and missionaries, which has great value as a historical source. Therefore, research on the relevant literature in this magazine can reveal much.

The first to write about Muslims in The Chinese Recorder was J. Edkins, a famous missionary and sinologist, who visited the mosque in Beijing and published "Notes on Mahommedanism in Peking" in 1868. This paper introduced the layout of the mosque, worship, Muslim customs, the Imam's duties, and so on. ${ }^{23}$

Furthermore, missionaries' work reported the uprising of the Hui Muslim people in the northwest, in addition to opium and alcohol prohibition. With the deepening of missionary activity in the mainland, the differences in missionaries' understandings of different regions gradually emerged. Missionaries in Nanjing enjoyed harmonious relations with Muslims, often visiting mosques to hold discussions with imams. In the eyes of Guangdong missionaries, however, Chinese Muslims were very much apart. Missionaries located in the areas where Muslims were highly concentrated, in the central and western regions, seemed to pay more attention to the analysis of the characteristics of the communities from the missionaries' own perspective. For example, missionaries found that many Muslims in Henan were leaders and businessmen who were more receptive to Christianity and that some indigenous mullahs in Gansu could read Arabic. However, the villagers were considered more ignorant, representing an opportunity for preaching.

The increasing contact with Muslims amplified missionary interest in the study of Islam. At this time, uninformed subconscious perceptions were gradually replaced by relational research, especially in the early 20th century, and these studies gradually became systematic and mature. In the Chinese Recorder and Missionary Journal, a large number of articles were published on the study and introduction of Islam in China, including the religion's history in the country, the classic works of Islam in China, the doctrine and culture of Islam, the number and distribution of Muslims, and the current situation of Muslims in China, etc. With the deepening of understanding and research, missionaries developed a considerable understanding of the problems of Chinese Muslims. Cultural differences meant they were unable to identify with some of these phenomena.

The understanding of missionaries described above leads to another logical conclusion: that in China, Islam was the enemy of Christianity and a threat to its spread. A large number of Chinese Muslim groups were determined to be Christianity's target in the beginning but this attitude gradually softened, partly due to missionaries' experience in the Muslim-concentrated areas of Africa and Northwest China, and also some church members' sense of duty. Moreover, in the 1920s, missionaries found that Islam in China was undergoing a reform movement, and this religion that refused to accept Christianity was making new efforts by preaching its position within the country.

More than 70 years later, the journal had published 40 or 50 articles about Muslims, mainly along the lines of papers, conference communications, bibliographic information, and introductions to works. Academic papers were the most common publications, mainly discussing the origin and development of Islam in China, Islamic classics, doctrines and regulations, characteristics of Chinese Muslims, and missionary strategies and methods, etc.

Moreover, there was a column called Our Book Table, introducing books published by missionaries. Although there are few articles about Chinese Muslims in the Journal of academic affairs, this may reflect the cognition and attitude of Western missionaries toward Chinese Muslims at that time, and also illustrate the situation when the two cultures were engaged in China.

\begin{tabular}{|l|}
\hline The Chinese Recorder and Missionary Journal \\
\hline J Edkins, "Note on Mahommedanism in Peking,” Vol. 2, No. 1, 1869. \\
\hline “Correspondence,” Vol. 10, 1878. \\
\hline “Notices of Recent Publications,” Vol. 13, 1882. \\
\hline Geo W. Clarke, “The Introduction of Mohammedanism into China,” Vol. 17, 1886. \\
\hline H V Noyes, “Mohammedanism,” Vol. 20, 1889. \\
\hline S C Hogg, "Mahommedanism, a Review,” Vol. 22, No. 6, 8, 9, 12, 1891. \\
\hline “The Real Mohammedanism.," Vol. 22, No. 7, July 1891. \\
\hline "Letters,” Vol. 40, 1909. \\
\hline
\end{tabular}

\footnotetext{
${ }^{23}$ J Edkins, 1869, "Notes on Mahommedanism in Peking” Chinese Recorder and Missionary Journal, Vol. 1, No. 1.
} 


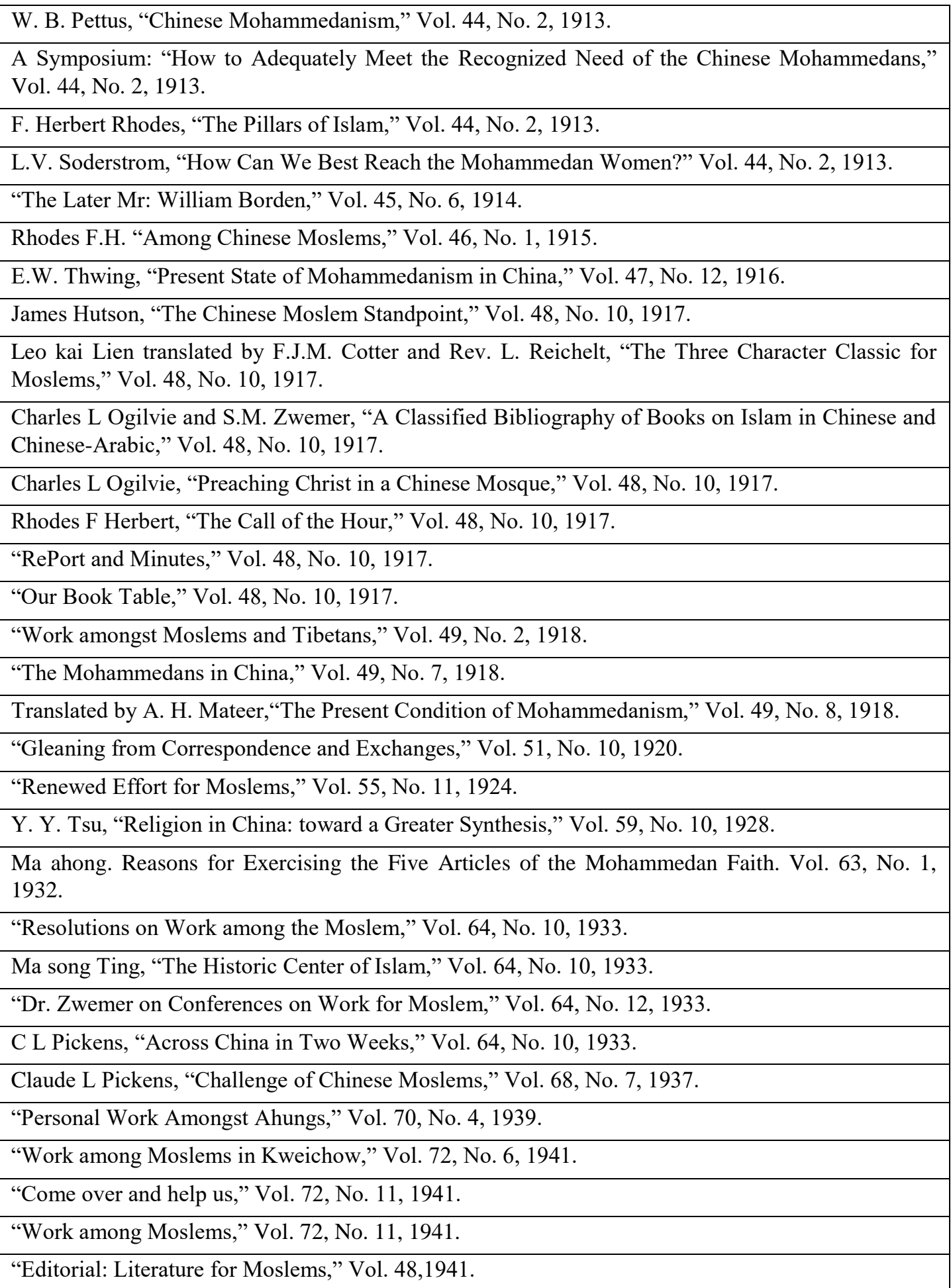

Some of the books in "Our Book Table" related to Muslim Studies, however; for example, the 10th issue of 1917 introduced Zwemer's "The Disintegration of Islam" and "Mohammed or Christ." This paper introduces the progress of missionary work among Muslims in detail.

The articles on Muslim issues published in The Chinese Recorder and Missionary Journal increased significantly from 1910. In February 1913 alone, the journal published more than 10 papers, newsletters, and symposiums in the form of albums. In the preparation stage, missionaries engaged in some tentative missionary activities among Chinese Muslims and prepared material. The biggest puzzle in this period for the missionaries was working out where Chinese Muslims had come from and identifying the characteristics they held. 
Regarding the introduction of Islam to China, French scholar Darby de Thiersant published his masterpiece Islam in China in Paris. This is the first monograph to comprehensively treat Islam in China. The book explores the history of the religion in China, and details the teaching, beliefs, and cosmology of Islam in the nation. One missionary introduced Darby's book in his paper "Correspondence." ${ }^{24}$ In 1889, H. V. Noyes, a missionary, introduced a systematic history of Chinese Muslims, with Darby de Thiersant's book as his main source. He agreed with de Thiersant's point of view that Islam was introduced during the Tang period, about 628 A.D. ${ }^{25}$

Geo W. Clarke and W. B. Pettus opposed this view in their paper, asserting that Muslims were persecuted in the Arabian Peninsula at that time, and Mecca had not been conquered; hence, it was unlikely that representatives would be sent to preach in distant China. They also mentioned some other viewpoints in the article: some believed that Islam was introduced to China by Arab merchants during the Sui dynasty. Their trade mainly came into Guangdong, Hangzhou, and other southeast coastal port cities. These trade contacts lasted for hundreds of years; in the process, they brought with them the revelation of the Prophet. ${ }^{26}$

Other theories on how Islam may have been introduced to China include the war in the western border area or the idea that astronomy scholars potentially brought Islam with them when exchanging astronomical phenomena and calendars. ${ }^{27}$

Another problem for missionaries was the population and distribution of Chinese Muslims. W. B. Pettus quoted the figures in Islam in China, published by Marshal Broomhall, and pointed out that China's Muslims numbered about 9 million, distributed in China's northwest and southwest. Nanjing functioned as a center for Muslims in the east of China, with 25 mosques, while a large number of Muslims also resided in Beijing. ${ }^{28}$

At this stage, the missionaries focused on the influential ancient books among Chinese Muslims. S. C. Hogg discovered a number of important Chinese Islamic documents, such as "huihuishuo", "Xiuzhen Mengyin", and "Tianfang Dianli". These were translated and explained systematically. They were published in The Chinese Recorder and Missionary Journal, and served as important references allowing the missionaries to share knowledge of Chinese Islam and prepare missionary materials accordingly. ${ }^{29}$

In October 1917, The Chinese Recorder and Missionary Journal published a set of documents about Muslims in the form of a special issue. This issue mainly comprised four aspects: the exploration of the Muslim spiritual world, an introduction to articles in other journals, the listing of Islamic documents in China, and a general focus on Islam.

Herbert Rhodes and James Hutson's papers described the five contributions of Islam in detail: specifically, reciting the Islamic program, worshiping, fasting, celestial lessons, and Hajji. The basic dogma of Muslims is introduced: the belief in the only true God, the celestial being, the Koran, the Prophet, the Future, the Judgment of the last world, and the Resurrection of faith. The text refers to the seven foundations of Islam: namely, God's laws, models, extra responsibilities, prescribed acts, proscribed acts, etc. ${ }^{30}$

The Chinese Recorder and Missionary Journal also selected articles from other journals. A Russian Archimandrite's sermon in 1866 titled "The Mohammedans in China" in Beijing, which was translated from Russian to English by Ms. Figourevaky and published in The Chinese Recorder and Missionary Journal in 1918. This paper discusses several statements about Islam's origins in China, introduces famous Chinese Muslims, such as Liu Zhi, and introduces the architectural style of mosques, marriage and burial customs, etc. ${ }^{31}$

The Chinese Recorder and Missionary Journal also published articles written by Muslims. In 1917, Yunnan's “Qingzhen Yuebao" was published, but it could not be maintained. The Chinese Recorder and Missionary Journal selected the article

24“"Correspondence, 1878," The Chinese Recorder and Missionary Journal, Vol. 10.

${ }^{25}$ H. V. Noyes, 1889, "Mohammedanism," The Chinese Recorder and Missionary Journal, Vol. 20.

${ }^{26}$ Geo W. Clarke, 1886, "The Introduction of Mohammedanism into China," The Chinese Recorder and Missionary Journal, Vol. 17. W. B. Pettus, 1913, "Chinese Mohammedanism,” The Chinese Recorder and Missionary Journal, Vol. 44, No. 2.

${ }^{27}$ W. B. Pettus, 1913, “Chinese Mohammedanism,” The Chinese Recorder and Missionary Journal, Vol. 44, No. 2.

${ }^{28}$ W. B. Pettus, 1913, "Chinese Mohammedanism”, The Chinese Recorder and Missionary Journal, Vol. 44, No. 2.

${ }^{29}$ S. C. Hogg, 1891, "Mahommedanism” (a review), The Chinese Recorder and Missionary Journal. Vol. 22, Nos. 6, 8, 9, 12.

${ }^{30}$ F. Herbert Rhodes, 1913, "The Pillars of Islam,” The Chinese Recorder and Missionary Journal, Vol. 44, No. 2. James Hutson, 1917, "The Chinese Moslem Standpoint," The Chinese Recorder and Missionary Journal, Vol. 48, No. 10.

31،"The Mohammedans in China”, The Chinese Recorder and Missionary Journal, Vol. 49, No. 7, 1918. 
"The Present Condition of Mohammedanism" in its founding issue, describing some of the problems encountered by Chinese Muslims at the time. ${ }^{32}$

Additionally, the famous Imam Ma Songting's "The Historic Center of Islam"33 and his speech "Reasons for Exercising the Five Articles of the Mohammedan Faith" 34 were also translated and published in The Chinese Recorder and Missionary Journal.

At this stage, the missionaries attached great importance to the collection and collation of Islamic literature in China, such as Liu Zhi's Tianfang Sanzijing, translated into English. Ogilvie and Samuel Marinus Zwemer, who used to be Secretary-General of the special committee for Muslim work, jointly collated 95 Chinese and Arabic Islamic classics. Their systematic organization and presentation of these influential ancient books has guided Western scholars of Chinese Islam and is also of great value to domestic academics in their further exploration of Islamic literature. ${ }^{35}$

From 1937 to 1945, the Second Sino-Japanese war had an impact on missionary work among Chinese Muslims. Missionary activity did not advance significantly and was basically in a state of maintenance. During this period, the number of relevant documents in the Journal of Academic Affairs decreased, but still included a brief introduction to the progress of Muslims' work in various regions, as well as a reflection on the gains and losses of Muslim missionary work.

\section{The Society of Jesus and Studies by French Orientalists}

The development of Western sinology can be divided into three periods. The earliest period - travel sinology - developed with the work of a number of travel writers, the most famous of whom being Marco Polo. The second sinology period is characterized by the missionaries: in this period, writings sent back by missionaries were the main source for the West's understanding of China. Moreover, the solid foundation created by the missionaries' work enabled the subsequent professional sinology period to develop rapidly. Of the Western countries, France was one of the earliest and most specialized in the development of sinology. French sinology research has a long history, rich content, and active thinking; this has invariably been valued by the international sinology community. With a history of nearly two hundred years, the influence of French sinology is far-reaching.

The cross-cultural engagement of Jesuit missionaries was mainly intended to enable the European upper class to learn more about China, in order to attract their support for missionary activities. However, considering the setbacks of previous missionary work, and in a country with a great history of civilization like China, the flexible approach of many Jesuit missionaries exceeded the expectations of those at home.

Under such a premise, the Jesuit missionaries were well positioned to understand the local conditions and customs of China, and the translation of Chinese works enabled cross-cultural exchange. In this way, the missionary activities of Jesuits were not only an opportunity for China to understand the West, but also a great opportunity for the West to likewise learn from the East.

\subsection{The Society of Jesus}

The Society of Jesus was founded in Paris in 1534 and approved by Pope Paul III in 1540. Its highest authority is the Jesuit guild, which is subordinate to the Pope, and it is divided into provincial capitals, cooperation areas, and independent provincial vice-capitals, etc. Members of the Society of Jesus must make a unique vow of obedience to the Pope.

Shortly after its establishment, the Society of Jesus began sending missionaries to Asia, Africa, and America, sending the first missionaries to China in the 16th century. The first Jesuit, Francis Saberi (1506-1552), arrived at Shangchuan Island in Guangdong Province in 1551 and died the next year. Subse quently, early Jesuits arrived in Macao and, in 1576, the Diocese of Macao was established. Before 1633, all European Jesuits bound for China set out from Lisbon and entered mainland China through Macao.

In 1583, The Society of Jesus member, Matteo Ricci (1552-1610), came to Guangdong, After 18 years in southern

\footnotetext{
${ }^{32}$ A. H. Mateer, 1918, “The Present Condition of Mohammedanism”, The Chinese Recorder and Missionary Journal, Vol. 49, No.8.

${ }^{33}$ Ma song Ting, 1933, “The Historic Center of Islam”, The Chinese Recorder and Missionary Journal, Vol. 64, No.10.

${ }^{34}$ Ma along, 1932, "Reasons for Exercising the Five Articles of the Mohammedan Faith", the Chinese Recorder and Missionary Journal, Vol. 63, No.1.

${ }^{35}$ Chas L. Ogilvie and S. M. Zwemer, 1917, "A Classified Bibliography of Books on Islam in Chinese and Chinese-Arabic", The Chinese Recorder and Missionary Journal, Vol. 48, No. 10.
} 
China, he finally entered Beijing in 1601. Over the next ten years, Matteo Ricci established a positive image among Chinese intellectuals thanks to his knowledge of mathematics, astronomy, and the Chinese classics. This model was also adopted by many other Jesuits who came to China.

In 1644, when the Qing dynasty began its rule, Emperor Shunzhi and Kangxi continued to use Western missionaries. Johann Adam Schall von Bell (1592-1666) and Ferdinand Verbiest (1623-1688) were successively appointed Chief of the Imperial Tianjian. The number of believers in the country reached 270,000.

Emperor Yongzheng began to suppress Catholicism and persecute Christians and missionaries in China, but a group of Jesuit scholars and artists were retained in Beijing's court. Italian painter Brother Giuseppe Castiglione S.J. and Fr. Michel Benoist S.J. were responsible for making maps.

In the late 17th century, Jesuit missionaries were the highest authority in the West when it came to understanding China.

In 1762, France issued the order to disband the Jesuits; and in July 1773, the Holy See announced the disbandment of Jesuits. The Jesuits were not able to recover until 1814. In 1842, three French Jesuits, Fr. Claude Gotteland S.J., Benjamin Brueyre S.J., and Francois Esteve S.J., returned to China. In 1847, missionary centers were officially established in Xujiahui, Shanghai (then a rural village), and featured an astronomical observatory, library, and museum, etc. As a diocese of Shanghai, the Jesuit Church, centered on Xujiahui, gradually spread Catholicism to the southern pastoral areas (Jiangsu and Anhui provinces) entrusted by the Holy See. By 1920, the number of believers had grown to 200,000 .

The academic activity of French missionaries in China mainly focused on two aspects: firstly, spreading Western scientific and technological knowledge; and secondly, introducing Chinese history and culture to Europe. Additionally, French Orientalists also worked hard to learn about Chinese culture and convey information about China to Europe.

The Society of Jesus missionary, Baijin, was one of the mathematicians sent to China by Louis XIV. He arrived in Beijing in 1688 and died there in 1730. In addition to a large number of letters, Baijin also wrote 14 works, including travel reports, biographies of Chinese emperors, Chinese dictionaries, and translations of Chinese philosophy. The seventh attachment in the second edition of German philosopher Leibniz's News from China is the biography of the emperor of China written by Baijin.

In the 18th century, the most important contribution of French Jesuits to the field of history was the publication of a 12 volume general history of China, based on the compendium of general learning by Zhuxi, a scholar of the Song dynasty. The editor, J.M.A. de Marilla, arrived in China in 1703 and died in Beijing in 1748. For the first time, the book systematically introduced Chinese history to the West, especially the history of the Ming and Qing dynasties. In 1785, the author added volume 13, "China's General Situation". Prior to this, the editor had already translated the compendium of general knowledge into French, paving the way for the writing of a general history. Thanks to the author's having participated in the surveying and mapping of China during the reign of Kangxi, the exposition of China's geography in his book is very precise.

In the study of ancient Chinese history, the greatest contribution was made by the missionary Antonius Gouhil. He was a master of literature, history, and natural science. He published a French translation the Confucian classic book of songs, and also wrote The History of the Tang Dynasty, The History of Chinese Astronomy, Genghis Khan and the History of Mongolia, among other things. Gouhil used original Chinese source material to connect the history of China and Western Asia. He held a large collection of unpublished manuscripts at the Paris Observatory, some of which were eventually published between 1809 and 1811 .

Among the French missionaries who came to China to preach, some had a profound knowledge of Ancient Chinese. They made continual efforts to translate many Chinese scriptures into Latin or French.

\subsection{French Orientalism and Related Studies}

The establishment of French sinology can be traced back to the first European sinology chair, established at the Collège de France in 1814; and the Far East and Indian American Religion chair which was established at the Ecole pratique des hautes études in 1889. Today, sinology has been internalized as a part of the French scientific research system. The current research system of "mixed research units" (unités mixtes de recherche) in France also had a significant impact on the development of sinology research. "Mixed research units" are mainly organized and jointly managed by the French National Research Center (Centre National de la Recherche Scientifique) in universities or other research institutions. This system greatly facilitates resource sharing and academic mobility.

As far as Chinese religious research is concerned, the important institutions that belong to the mixed research unit are: the East Asian Civilization Research Center (Centre de Recherche sur les Civilisations de l'Asie Orientale), the Institute of Social, Religious, Political and Religious Relations (Groupe Sociétés, Religions, Laïcités), and the Joint Research 
Center of China, South Korea, and Japan (Centre Chine-Coree-Japon). The Far East College (Ecole Française d'Extrême-Orient) and the Sinology Research Institute of France (Institut des hautes études chinoises) are also important institutions of sinology research.

These mainland China-focused research institutions also conduct academic research on religion in China, including Buddhism, Taoism, Islam, and others. Darby de Thiersant, Gabriel Deveria, and other scholars were representative Oriental scholars who studied Islam and Muslim issues inside China.

$\$$ French Orientalist Darby de Thiersant's representative works were two volumes of Le Mahometisme en Chine (Islam in China), published in Paris in $1878 .{ }^{36}$ During the writing process, which took 15 years to complete, the author enjoyed the assistance of many Chinese Muslims, and also obtained much material from Catholic priests all over China. The first volume of the book discusses the origin of Chinese Muslims and describes the different Islamic characteristics of various regions, such as Gansu, Yunnan, Guangdong, Shannxi, and the Central Plains The second volume describes in detail the doctrines, beliefs, and cosmology of Chinese Islam. The missionaries cited it as an authoritative work on Islam in China.

The work quoted many famous Chinese and Islamic classics, including, among others: Zhengiiao Zhenquan, Xiuzhen Mengyin, Qingzhen Zhinan, Tianfang Xingli, Tianfang Dianli, Dahua Zonggui, Youming Jieyi. An overview can be found in Wei Yingbang's On the study of Chinese Islam by foreign scholars. ${ }^{37}$

QGabriel Deveria's book, Origine de l'islamisme en Chine, ${ }^{38}$ although relatively brief, aimed to trace the origin of Islam in China by examining popular Chinese Muslims legends. The book was proclaimed "the best and most important of all the published works on this issue to date" by 海恩波.

Oriental scholars who have also been engaged in the study of mainland Chinese Islam and Muslim issues include Henri d'Ollone, Arnold Jacques Vissière, Darby de Thiersant, Georges Cordier, and Paul Pelliot. Their research will be introduced in the next chapter. ${ }^{39}$

Europeans naturally had a great curiosity about China in this period. The Jesuits took advantage of this curiosity to stimulate European support of missionary enterprise in China.

\section{Results}

Prior to the 19th century, there was no academic research in the modern sense of the word. In the 19th century, the development of natural science and the emergence of the Enlightenment gradually gave birth to social science in modern Europe. As Europe opened the door to China in the middle of the 19th century, Western academia began to pay attention to China, and Western theories and methods progressively entered China and were accepted by Chinese scholars. In particular, a number of Christian missionaries and Orientalists completed more serious studies of Islam in China, and published their research.

The missionaries' attention to Islam in China derived from the needs of missionary work. They were familiar with Islam and regarded it as an important competitor to Christianity. Russian Orthodox missionaries were the first to collect information about Chinese Islam, and after the turn of the 20th century, British and American missionaries began to turn their attention to this area.

When Western missionaries entered China, they discovered the presence of a large Muslim group, so they began to study them and organize missionary work aimed at them. Although this missionary activity proved unsuccessful in terms of the number of converts to Christianity, it had a certain positive significance regarding religious and cultural exchange, and cross civilizational interaction.

In the field of Orientalism, French academics have had a profound impact in Chinese Islamic studies. Originally, the cultural contact made by Jesuit missionaries was mainly intended to enable the European upper classes to learn more about China - a remote country - and thereby attract their support for missionary work. Considering the setbacks of previous missionary activity, and in a country with a great civilizational history like China, the Jesuit missionaries' flexible approach often proved favorable.

\footnotetext{
${ }^{36}$ Darby de Thiersant, 1878, Le mahométisme en Chine, Paris: Ernest Leroux.

${ }^{37}$ Wei Yingbang, "On the Study of Chinese Islam by Foreign Scholars," in the treatise on Islam in Qing Dynasty, compiled by the Ningxia Institute of Philosophy and Social Sciences, Ningxia people's Publishing House, 1981, pp. 340-364.

${ }^{38}$ Gabriel Deveria, 1895, Origine de l'islamisme en Chine, Paris: Imprimerie Nationale.

${ }^{39}$ Wang Junjun, 2014, “Chinese Culture Communication by French Missionaries in the 17-18th Century," Liaoning University, Masters Thesis.
} 
The Jesuit missionaries were well placed to study and understand the local conditions and customs of China, and the translation of Chinese literature was an important feature of their work. In this way, the missionary activities of Jesuits represented not only an opportunity for China to understand the West, but also a great opportunity for the West to learn from the East.

The establishment of French sinology can be traced back to the establishment of the first European sinology chair, at the Collège de France in 1814. In 1889, France also saw the launch of a religious research chair in sinology: the "Far East and Indian American Religions" chair at the École pratique des hautes études. The French system greatly facilitated resource sharing and academic mobility.

These mainland China-related research institutions also conducted research on the Chinese religions, including, among others, Buddhism, Taoism, and Islam. Important Oriental scholars of Islam and Muslim issues in China include the likes of Darby de Thiersant and Gabriel Devéria.

Valuable French research material includes the collection of a number of inscriptions on mosques in China, including Arabic rubbings and photos, which vividly describe the life of Chinese Muslims at that time.

The missionary work of the Western Christian Church in China reached its climax in the 19th century. In 1865, the China Inland Mission, or CIM (a transnational missionary organization) was founded by English missionaries, including Hudson Taylor. The missionaries sent to China came from different denominations, mainly from Britain, the United States, Canada, and New Zealand. Some missionaries also hailed from Germany, Austria, and Northern Europe (from countries such as Sweden, Norway, Finland, and Denmark). The CIM asked missionaries to devote themselves regardless of payment and submit themselves to "Chinization". As a result, they became the vanguard of missionaries in mainland China. Everywhere they went, they set up missionary stations and then expanded rapidly in to the most remote areas. By the end of the 19th century, the CIM had about 650 missionaries, 270 missions, and 5000 believers, becoming the largest Protestant group in China. This is the context in which missionaries began to investigate and study Islam in China, with the objective of the advancement of their missionary work to Muslims.

Some missionaries wrote about the uprising of the Hui Muslim people in the northwest, in addition to articles on opium and alcohol prohibition. With the deepening of missionary activity in the mainland, the differences in missionaries' understandings in China's regions gradually emerged. The missionaries in Nanjing found that they and Muslims could maintain good relationships: missionaries often visited mosques to discuss with imams and the relationships were relatively harmonious. In the eyes of Guangdong missionaries, however, Chinese Muslims were very much apart. Missionaries located in the areas where Muslims were highly concentrated, in the central and western regions, seemed to pay more attention to the analysis of the characteristics of the communities from the missionaries' own perspective. For example, missionaries found that many Muslims in Henan were leaders and businessmen who were more receptive to Christianity; some indigenous mullahs in Gansu could read Arabic. However, the villagers were considered more ignorant, representing an opportunity for preaching.

Generally speaking, in the second half of the nineteenth century, Western academics had begun to contact and pay attention to Muslims and Islam in mainland China. During this period, missionaries and Orientalists completed much data collection work. However, a lot of this material was not published at the time, and therefore did not have an impact. However, the pioneering value of this work should be recognized, representing, as it did, the first contemporary academic study on Islam in China. Indeed, many articles in this period related to the Muslim uprising in the late Qing dynasty. Generally, Western study of Islam in China was connected with the study of China as a whole.

\section{Acknowledgements}

I am immensely grateful for the research environment provided by Tohoku University of Japan, in particular the Frontier Research Institute for Interdisciplinary Sciences, and the teachers and administrators of the Institute. I especially want offer thanks to Prof. Toshiyuki Hayase (Director of the Frontier Research Institute for Interdisciplinary Sciences, Tohoku University) and Prof. Takashi Kuroda (Graduate School of International Cultural Studies, Tohoku University). Thanks are also due to the Faculty of Oriental Studies, University of Oxford, in particular, Prof. Christopher Melchert. This project would not have been completed without the Faculty's help and support.

This work was supported by "Leading Yong Researcher Overseas Visit Program" (Tohoku University, JAPAN), February 1, 2020 to January 31, 2021(one year), Research University: University of Oxford (Faculty of Oriental Studies).

\section{References}

"The Mohammedans in China". The Chinese Recorder and Missionary Journal, 49(7), 1918.

A. H. Mateer. (1918). The Present Condition of Mohammedanism. The Chinese Recorder and Missionary Journal, 
49(8).

Alvyn, A. (2003). Only Connect: The China Inland Mission and Transatlantic Evangelicalism”, in North American Foreign Missions, 1810-1914: Theology, Theory, and Policy, ed. Wilbert R. Shenk (London: Gurzon and Grand Rapids: Eerdmans).

Alvyn, A. (2006). China's Millions: The China Inland Mission and Late Qing Society, 1832-1905. Mich.: Wm. B. Eerdmans Publishing Company.

Archimandrite, Р. (Архимандрит Палладий). (1866). Secret History of Yuan Dynasty. Works of Members of the Russian Missionary Group in Beijing, 4.

Archimandrite, Р. (Архимандрит Палладий). (1872). The Ancient Traces of Christianity in China. Oriental Anthology, 1.

Archimandrite, Р. (Архимандрит Палладий). (1887). Selected works of Islamic Chinese. St. Petersburg.

Chas, L. O., \& S. M. Zwemer. (1917). A Classified Bibliography of Books on Islam in Chinese and Chinese-Arabic. The Chinese Recorder and Missionary Journal, 48(10).

Darby de Thiersant. (1878). Le mahométisme en Chine, Paris: Ernest Leroux.

Du, Y. B. (2009). The Research on the Activity of the China Inland Mission in the Modern Northwest Muslim Society. Master Thesis of Xinjiang Normal University.

Du, Y. B. (2009). The Research on the Activity of the China Inland Mission in the Modern Northwest Muslim Society, Master Thesis of Xinjiang Normal University, 2009.

F. Herbert Rhodes. (1913). The Pillars of Islam. The Chinese Recorder and Missionary Journal, 44(2).

Gabriel, D. (1895). Origine de l'islamisme en Chine, Paris: Imprimerie Nationale.

Geo, W. C. (1886). The Introduction of Mohammedanism into China. The Chinese Recorder and Missionary Journal, Vol. 17. W. B. Pettus, 1913, “Chinese Mohammedanism. The Chinese Recorder and Missionary Journal, 44(2).

H. V. Noyes. (1889). Mohammedanism. The Chinese Recorder and Missionary Journal, 20.

Hyacinth, Y. В. (Никита Яковлевич Бичурин), The Compilation of the Historical Materials of the Ancient Central Asian Nations, St. Petersburg, 1851.

Hyacinth, Y. В. (Никита Яковлевич Бичурин). (1833). The History of Tibet and Qinghai (2282-1227BC), St. Petersburg.

Hyacinth, Y. В. (Никита Яковлевич Бичурин). (1834). The History of the Irutos and Kalmecks since the 15th century, St. Petersburg.

J Edkins. (1869). Notes on Mahommedanism in Peking. Chinese Recorder and Missionary Journal, 1(1).

James, H. (1917). The Chinese Moslem Standpoint. The Chinese Recorder and Missionary Journal, 48(10).

Liu, X. H. (2012). Study on The Missionary Work by The China Inland Mission to Moslems in Northwest of China (1876-1951), Doctoral dissertation, Central China Normal University, 2012.

Ma along. (1932). Reasons for Exercising the Five Articles of the Mohammedan Faith. the Chinese Recorder and Missionary Journal, 63(1).

Ma song T. (1933). The Historic Center of Islam. The Chinese Recorder and Missionary Journal, 64(10).

P. K. I. Quishtad. (1979). 1857-1960 Russian expansion in the far East. The Commercial Press.

Raphael Israeli (1995). The Cross Battles the Crescent, One Century of Missionary Work among Chinese Muslims, 1985-1950. Modern Asian Studies, 29(1), 1995. https://doi.org/10.1017/S0026749X00012671

S. C. Hogg. (1891). "Mahommedanism" (a review). The Chinese Recorder and Missionary Journal, $22(6), 8,9,12$.

Vasili, P. V. (1960). Islam in China. Central Asian Collectanea.

Vasili, P. V. (2007). The History and monuments of Eastern Central Asia in the 10th - 13th Century" (1859) in Zhao Chunmei: "Vasilev and China", Xuefan publishing house.

Vasili, P. V. (2014). History of Chinese Literature. China's Publishing House, p. 168.

W. B. Pettus. (1913). Chinese Mohammedanism. The Chinese Recorder and Missionary Journal, 44(2).

Wang, J. J. (2014). Chinese Culture Communication by French Missionaries in the 17-18th Century. Liaoning University, Masters Thesis. 
Wei, Y. B. (1981). "On the Study of Chinese Islam by Foreign Scholars," in the treatise on Islam in Qing Dynasty, compiled by the Ningxia Institute of Philosophy and Social Sciences, Ningxia people's Publishing House, 1981, pp. 340-364.

Wu, K. M. (1985). A Brief History of Russian Orthodox Invasion of China. Gansu People's Publishing House.

Zhao, C. M. (2007). Vasilev and China. Xuefan publishing house, pp. 219.

\section{Copyrights}

Copyright for this article is retained by the author(s), with first publication rights granted to the journal.

This is an open-access article distributed under the terms and conditions of the Creative Commons Attribution license which permits unrestricted use, distribution, and reproduction in any medium, provided the original work is properly cited. 